\title{
PRODUKSI KARIMPU DAN EFEKNYA DALAM MEMPERBAIKI PROFIL LIPID
}

\section{Karimpu Production and The Effect on Improving Lipid Profile}

\author{
Hery Winarsi $^{1 *}$, Adi Amurwanto ${ }^{2}$, Sri Sutji Susilowati ${ }^{3}$ \\ ${ }^{1}$ Program studi Ilmu Gizi, Fakultas Ilmu-ilmu Kesehatan, Universitas Jenderal \\ Soedirman; ${ }^{2}$ Fakultas Biologi Universitas Jenderal Soedirman; ${ }^{3}$ Jurusan Farmasi, \\ Fakultas Ilmu-ilmu Kesehatan, Universitas Jenderal Soedirman; *Alamat \\ korespondensi: winarsi12@gmail.com
}

\begin{abstract}
This study aims to counseling and training Karimpu (drink rich in antioxidant cardamom rhizome) production, and to know that effects on total cholesterol, triglycerides, LDL, and HDL plasma women with hypercholesterolemia. The trainees were 20 mothers from Ciberem village, Sumbang, Banyumas district. Karimpu drinks are composed of chip rimpang cardamom and spices. As the subject of the intervention study were 30 women with hypercholesterolemia, obesity, age 45-65 years, living in Purwokerto area, willing to sign informed consent. Randomly subjects divided into 3 groups of 10 people each; I, given statin + Karimpu; II, statin + plasebo; III, statin for 2 months. Blood samples were taken twice, 0 and 2 months after intervention, and centrifuged. The plasma was tested for total cholesterol, LDL, triglyceride, and HDL level. People enthusiastically attended counseling and training showed test results increased 46.1\%. The Karimpu product decreases cholesterol $(P=3,71 E-07)$ and LDL $(P=0.0009)$, and otherwise increases $H D L(P=$ $0.014)$, and retains triglyceride ( $P>0.05)$. Therefore, karimpu is able to inhibit the development of hypercholesterolemia towards cardiovascular disease by improving lipid profile.
\end{abstract}

Keywords: Cardamom rhizome drink, lipid profile, training production.

\begin{abstract}
ABSTRAK
Penelitian ini bertujuan untuk memberikan pelatihan produksi Karimpu (minuman kaya antioksidan rimpang kapulaga) dan mengetahui efeknya terhadap kadar kolesterol total, trigliserida, LDL, dan HDL wanita penderita hiperkolesterolemia. Peserta pelatihan adalah 20 ibu-ibu dari desa Ciberem, Sumbang, Kabupaten Banyumas. Minuman Karimpu tersusun atas chip rimpang kapulaga dan rempah-rempah. Sebagai subjek untuk diintervensi adalah 30 wanita dengan hiperkolesterolemia, obesitas, usia 45-65 tahun, tinggal di daerah Purwokerto, dan bersedia untuk menandatangani informed consent. Subjek secara acak dibagi menjadi 3 kelompok, masing-masing 10 orang; I, diberi statin + Karimpu; II, statin + plasebo; dan III, statin, selama 2 bulan. Sampel darah diambil 2 kali, 0 dan 2 bulan setelah intervensi, lalu disentrifugasi. Bagian plasma ditentukan kadar kolesterol total, LDL, trigliserida, dan HDL. Peserta antusias mengikuti penyuluhan dan pelatihan produksi karimpu, ditunjukkan hasil tes meningkat 46,1\%. Karimpu menurunkan kadar total kolesterol $(P=3,71 E-07)$ dan $\operatorname{LDL}(P=0,0009)$, dan sebaliknya meningkatkan HDL $(P=0,014)$, dan mempertahankan trigliserida $(P>0,05)$. Dengan demikian, karimpu diyakini dapat menghambat perkembangan hiperkolesterolemia terhadap penyakit kardiovaskular dengan cara memperbaiki profil lipid.
\end{abstract}

Kata kunci: minuman rimpang kapulaga, profil lipid, pelatihan produksi

\section{Pendahuluan}

Hiperkolesterolemia adalah

kondisi dengan kadar kolesterol dalam darah lebih tinggi dibanding batas normal, yaitu lebih dari $200 \mathrm{mg} / \mathrm{dl}$ (Listiyana et al., 2013). Kondisi demikian 
meningkatkan risiko terjadinya penyakit jantung dan pembuluh darah sebesar 1,8 kali lebih besar dibandingkan dengan kolesterol darah normal (Doyle et al., 1964; Gander et al., 2014). Hiperkolesterolemia berkaitan erat dengan aterosklerosis. Kolesterol, pengangkutannya ke seluruh tubuh dilakukan HDL dan LDL. LDL mengangkut kolesterol dari hati ke dalam jaringan untuk berfungsinya tubuh, sedangkan HDL mengangkutnya dari jaringan ke hati. Bila kadar LDL lebih tinggi dari normal dapat terakumulasi dalam pembuluh darah dan meningkatkan resiko pembentukan plak yang menyumbat pembuluh darah arteri. Pada lesi aterosklerosis ditemukan LDL yang lebih elektronegatif dibandingkan dengan LDL native (Mitra et al., 2011). Dapat diyakini bahwa yang berperan dalam aterogenesis bukan LDL native, melainkan LDL yang teroksidasi (LDLox) (Zhu et al., 2005), akan tetapi terbentuknya LDL-OX merupakan dampak tingginya kadar LDL. Karena itu sangat penting dilakukan minimalisasi kadar LDL-ox ataupun LDL.

Hiperkolesterolemia diyakini mengganggu fungsi endotel dengan memproduksi radikal bebas oksigen. Terkait hal tersebut, Cave (2007) menyatakan bahwa hiperkolesterolemia dapat meningkatkan aktivitas tiga enzim utama pembentuk oksidan yaitu NADPH oxidase (NOX), xanthine oxidase, dan myeloperoxidase. NOX bertindak untuk mentransfer elektron ke molekul oksigen membentuk superoksida dan pada akhirnya $\mathrm{H}_{2} \mathrm{O}_{2}$. Karena itu Kuamsub et al. (2017) menegaskan bahwa senyawa antioksidan dapat memperbaiki profil lipid tanpa efek samping.

Rimpang kapulaga dilaporkan Winarsi et al. (2016a) mengandung antioksidan flavonoid sebesar 324,51 mg/g, hampir 3 kali lipat kadarnya dalam daun kapulaga, dan 15 kali lipat kadarnya dalam batang kapulaga. Ekstrak rimpang kapulaga yang diberikan kepada tikus aterosklerosis selama 2 minggu, terbukti menurunkan kadar kolesterol, LDL-c, LDL-ox (Winarsi et al., 2016a), trigliserida, MDA, IL-6, dan CRP (Winarsi et al., 2016b), dan sebaliknya meningkatkan kadar HDL (Winarsi et al., 2016a; Winarsi, 2015). Rimpang kapulaga juga telah diformulasikan menjadi minuman fungsional yang disebut Karimpu oleh Winarsi dan Hernayanti (2016a). Minuman tersebut diketahui kaya antioksidan fenolik $(498.8 \pm 0.01 \quad$ ppm), lebih besar dibandingkan minuman rimpang jahe (447.93 ppm) temuan Ibrahim et al. (2015). Selain antioksidan fenolik, 
minuman berbasis rimpang kapulaga juga mengandung vitamin $\mathrm{C}(36 \mathrm{mg} / 100 \mathrm{~g})$, lebih tinggi dibandingkan minuman kunyit asam $(0,688 \mathrm{mg} / 100 \mathrm{~g})$ seperti yang dilaporkan Mulyani et al. (2014). Minuman tersebut rasanya manis, semriwing, menghangatkan tubuh, dan terdapat aftertaste yang disukai (Winarsi dan Hernayanti, 2016b). Namun demikian, produk Karimpu ini belum diketahui masyarakat luas.

Beberapa peneliti menyatakan bahwa senyawa antioksidan mampu menekan inflamasi (Winarsi et al., 2013b; Zhang et al., 2011), dan melindungi membran sel endotel dengan cara modulasi profil lipid (Squadrito et al., 2003; Winarsi et al., 2013a). Hingga saat ini masyarakat belum mengenal Karimpu, demikian pula potensi Karimpu dalam memperbaiki profil lipid juga belum ada data yang mengungkapnya. Karena itu penelitian ini bertujuan untuk sosialisasi dengan cara penyuluhan dan pelatihan produksi Karimpu, serta mengetahui efek minuman tersebut terhadap kadar kolesterol total, trigliserida, LDL, dan HDL plasma wanita penderita hiperkolesterolemia.

\section{Metode penelitian}

\section{a) Penyuluhan dan Pelatihan Produksi minuman berbasis}

\section{rimpang kapulaga (Karimpu)} (Winarsi dan Hernayanti, 2016)

Peserta pelatihan sebanyak 20 ibu-ibu dari desa Ciberem, Sumbang, kabupaten Banyumas. Dipilihnya Ciberem sebagai tempat pelatihan karena desa tersebut adalah salah satu desa yang sebagian lahannya ditanami kapulaga. Harapannya, masyarakat desa tersebut dapat memanfaatkan rimpang kapulaga (menjadi produk Karimpu), yang biasanya dibuang ketika para petani kapulaga melakukan penghijauan tanamannya.

Mula-mula rimpang kapulaga yang diperoleh dari petani apulaga di desa Sumbang, Kabupaten Banyumas, Jawa Tengah, di cuci bersih, diiris tipis-tipis, dikeringkan dengan cahaya matahari atau di oven sampai kering, disebut chip rimpang kapulaga (CRK) (Winarsi et al., 2015 dengan modifikasi). Minuman fungsional berbasis rimpang kapulaga tersusun atas CRK, kayu secang, kayu manis, cengkih, bunga lawang, jahe, sereh, daun jeruk purut, pemanis rendah kalori, dan sedikit garam serta air (Winarsi and Hernayanti, 2016).

\section{b) Seleksi subjek penelitian}

$$
\begin{array}{rrrr} 
& \text { Sebagai } & \text { subjek } & \text { penelitian } \\
\text { adalah } & 30 & \text { wanita } & \text { penderita }
\end{array}
$$


hiperkolesterolemia dengan kadar kolesterol > $200 \mathrm{mg} / \mathrm{dl}$ (Listiyana et al., 2013), dan obesitas (BMI > 25 $\mathrm{kg} / \mathrm{m}^{2}$ ) (Nishida, 2004), umur 45-65 tahun, tinggal di wilayah Purwokerto, bersedia mengikuti penelitian dengan menandatangani informed consent. Secara acak subjek dibagi 3 kelompok masing-masing 10 orang.

\section{c) Intervensi Karimpu kepada subyek}

Semua kelompok minum statin dari dokter pemeriksa. Kelompok pertama ditambahkan Karimpu, kedua diberi plasebo (Karimpu tanpa CRK), dan ketiga hanya minum statin. Intervensi dilakukan selama 2 bulan berturutturut. Karimpu dan plasebo diberikan setiap hari satu kali, sebanyak 100 $\mathrm{ml} /$ hari, dan diantar ke rumah subjek setiap pagi antara pukul 06.00-08.00 untuk langsung diminum.

\section{d) Pengambilan sampel darah dan pengujian}

Sampel darah masing-masing sebanyak $3 \mathrm{ml}$ diambil intravena, 2 kali yaitu saat baseline dan 2 bulan setelah intervensi. Pengambilan sampel darah menggunakan venojek yang mengandung EDTA $10 \%$. Sampel darah disentrifuse dengan kecepatan $3.000 \mathrm{rpm}$ selama 10 menit, untuk dipisahkan bagian plasmanya, kemudian dilakukan pengujian.

\section{e) Analisa statistik}

Data ditampilkan sebagai rata-rata \pm SD. Data yang diperoleh dianalisis menggunakan Anova, dilanjutkan uji Duncan bila terdapat signifikansi dengan tingkat kesalahan $5 \%$.

\section{Hasil dan pembahasan}

\section{a. Penyuluhan dan pelatihan produksi Karimpu}

Sebelum dilakukan pelatihan produksi karimpu, diadakan Pre-test untuk mengukur pengetahuan peserta tentang karimpu. Demikian pula setelah selesai kegiatan ini juga dilakukan Posttest. Harapannya, masyarakat desa Ciberem yang terlibat dalam kegiatan ini ada peningkatan pengetahuan, khususnya tentang minuman Karimpu, cara pembuatan, dan manfaatnya untuk kesehatan. Adapun yang hadir dalam kegiatan ini sebanyak 20 orang, dan 10 diantaranya adalah istri petani kapulaga.

Hasil pre-test rata-rata sebesar 65,88 , artinya peserta kegiatan mendapat 
nilai C (cukup). Setelah pre-test dilanjutkan penyuluhan tentang Karimpu, Minuman Kaya Antioksidan Rimpang Kapulaga, kandungan gizi, dan manfaatnya. Dalam penyuluhan ini diungkap tuntas bahwa rimpang kapulaga mengandung beberapa senyawa antioksidan seperti fenolik, flavonoid, dan vitamin C. Karena itu rimpang tersebut dapat dibuat produk minuman yang kaya antioksidan, seperti yang dilaporkan Winarsi dan Hernayanti (2016). Minuman tersebut disebut
Karimpu, karena terbuat dari rimpang kapulaga ditambahkan berbagai rempahrempah yang banyak ditemui di pasarpasar, yaitu kayu secang, kayu manis, cengkih, jahe, bunga lawang, daun jeruk, gula, dan garam. Wujud minuman Karimpu adalah cairan, warnanya coklat kemerahan, aromanya seperti minuman berbasis rimpang-rimpangan, yang telah beredar di pasar. Kandungan kimia minuman Karimpu dipaparkan pada Tabel 1 berikut.

Tabel 1. Kandungan kimia Karimpu

\begin{tabular}{lc}
\hline \multicolumn{1}{c}{ Komponen } & Karimpu \\
\hline Kadar air (\%) & $98,57 \pm 0,01$ \\
Kadar abu (\%) & $0,01 \pm 0,00$ \\
Kadar Protein (\%) & $0,15 \pm 0,01$ \\
Kadar lemak (\%) & $0,01 \pm 0,00$ \\
Kadar karbohidrat (\%) & $1,27 \pm 0,00$ \\
Kadar total fenol (mg/100 g) & $49,88 \pm 0.01$ \\
Kadar vitamin C (mg/100 g) & $31 \pm 0.01$ \\
Kadar flavonoid (mg/100 ml) & $83 \pm 0.01$ \\
\hline
\end{tabular}

Sumber: Winarsi dan Hernayanti (2016) 
Begitu antusiasnya, selama penyuluhan berlangsung peserta banyak yang interupsi untuk menanyakan sesuatu terkait dengan "Karimpu". Setelah dirasa telah paham dengan Karimpu, dilanjutkan post-test. Post-test dilakukan untuk mengetahui seberapa besar teori yang diserap oleh peserta. Nilai post-test sebesar 96,23, sangat baik, artinya peserta sudah paham betul tentang produk yang dibuat berbasis rimpang kapulaga.

Selesai penyuluhan diberikan pelatihan produksi Karimpu. Penambahan rempah-rempah tersebut mengadopsi pada kebiasaan masyarakat di kota Jogyakarta, yang sering minum "wedang uwuh" yang didalamnya mengandung bermacam-macam rempah. Terdapat bermacam-macam pemanis, tetapi dipilih pemanis low calorie yang tidak mempengaruhi kadar gula darah. Seperti halnya biji kapulaga, bahwa rimpang kapulaga juga memiliki rasa pedas, aroma menyengat, agak pahit, tetapi menghangatkan tubuh.

\section{b. Efek Karimpu terhadap profil lipid}

Kadar kolesterol total ditentukan dengan metode CHOD-PAP (Cholesterol Oxidase-Peroxidase Aminoantipyrine Phenol). Awalnya kadar kolesterol total tidak berbeda diantara tiga kelompok $(\mathrm{p}=0,60)$, namun 2 bulan setelah intervensi pada kelompok Karimpu, kadarnya menurun dari 291 menjadi $186,3 \mathrm{mg} / \mathrm{dl}(p=3,71 E-07)$, demikian pula pada kelompok plasebo juga menurun dari 294,3 menjadi 209,7 $\mathrm{mg} / \mathrm{dl}$ $(P=7,84 E-05)$. Meskipun penurunan kadar kolesterol terjadi signifikan dalam plasebo, tetapi kadarnya masih lebih tinggi dari normal. Sementara itu dalam kelompok statin kadar kolesterol tidak berubah $\quad(p=0,72) \quad($ Gambar 1). 


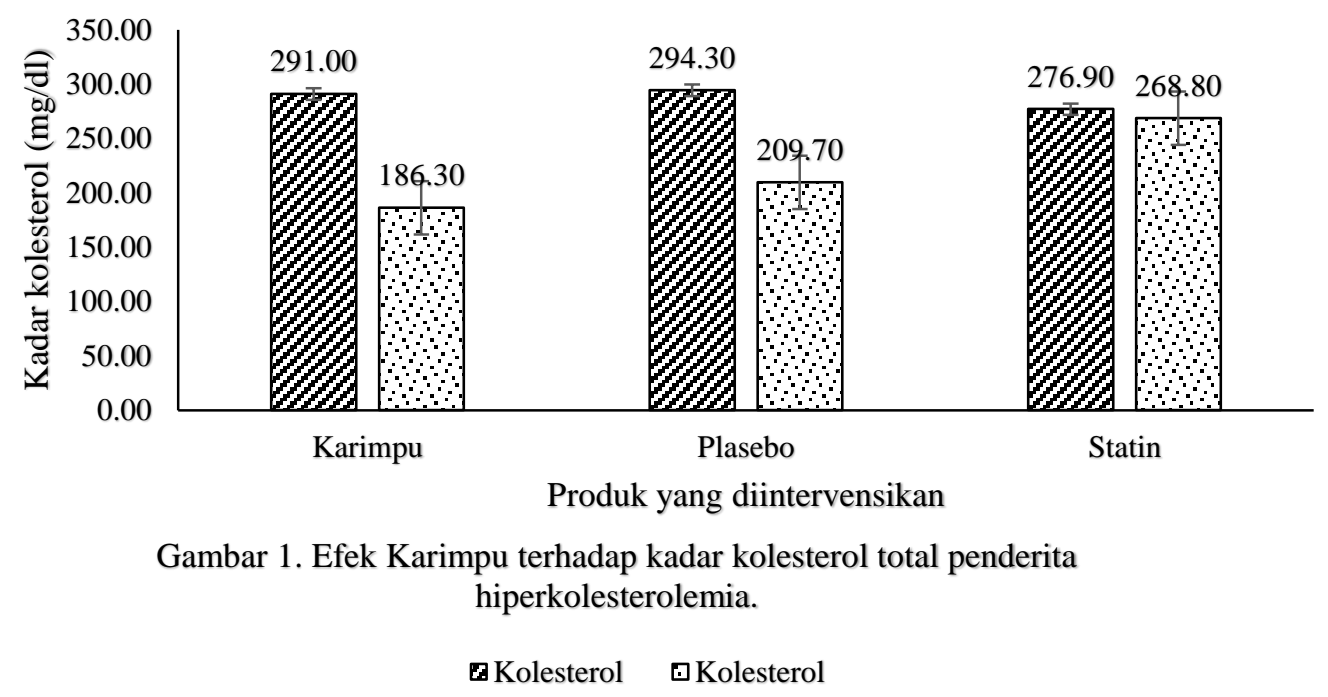

Tingginya kadar kolesterol total dan lipoprotein densitas rendah (LDL) ditetapkan sebagai faktor risiko aterosklerosis, dan merupakan penyebab utama penyakit kardiovaskular (PKV), tetapi tingginya kadar lipoprotein densitas tinggi (HDL) diyakini sebagai pelindung dan anti-inflamasi (Chrysohoou et al., 2006). Dalam penelitian ini subjek mengalami hiperkolesterolemia $(287,4$ $\mathrm{mg} / \mathrm{dl})$, LDL tinggi $(167,76 \mathrm{mg} / \mathrm{dl})$, dan sebaliknya HDL rendah $(37,37 \mathrm{mg} / \mathrm{dl})$. Kondisi demikian, jelas beresiko terhadap penyakit kardiovaskular (PKV). Namun demikian, kadar kolesterolnya menurun, demikian pula kadar LDL, dan sebaliknya kadar HDL meningkat untuk kelompok yang minum Karimpu. Kemungkinan, senyawa fenolik dalam Karimpu berperan dalam penurunan kadar kolesterol. Temuan ini mendukung hasil penelitian Winarsi et al. (2016) bahwa flavonoid (salah satu jenis fenolik) rimpang kapulaga menurunkan kadar kolesterol total tikus atherosclerosis yang diinduksi epinephrine.

Menurut Prahastuti et al. (2011) fenolik ataupun flavonoid mampu menghambat aktivitas enzim HMG CoA reduktase, sehingga menurunkan sintesis kolesterol, dan akhirnya kadarnya dalam darah menurun. Flavonoid juga mampu menghambat absorpsi kolesterol dalam usus, sehingga kadarnya menurun (Olivera et al., 2007). Melalui perannya sebagai inhibitor absorpsi kolesterol, flavonoid menghambat pembentukan 
misel dan menekan absorpsinya.

Penghambatan absorbsi kolesterol oleh flavonoid di usus, karena terjadi kompleks flavonoid - kolesterol yang bersifat tidak larut, kemudian berikatan dengan asam empedu dan membentuk misel. Fenolik yang telah berikatan dengan asam empedu kemudian meningkatkan ekskresi feses.

Kolestiramine (sequestrant asam empedu) mengganggu sirkulasi asam empedu enterohepatik dengan cara melepaskannya dan mencegah reabsorpsinya di usus. Konsekuensinya, terjadi pengurangan pool asam empedu. Makin banyak kolesterol diubah menjadi asam empedu menyebabkan kadar kolesterol plasma menurun (Insull, 2006; Ngamukote et al., 2011). Melalui mekanisme ini, kemungkinan karimpu menurunkan kadar kolesterol plasma.

Setelah konsumsi Karimpu, kadar HDL naik dari 36,69 menjadi 44,26 $\mathrm{mg} / \mathrm{dl} \quad(p=0,014)$, demikian pula yang terjadi pada kelompok plasebo dan statin kadarnya juga naik tetapi tidak signifikan $(p=0,09)$ dan $(p=0,71) \quad($ Gambar 2). Temuan ini mendukung Cicerale et al. (2010) yang menyatakan bahwa dalam tubuh 200 pria sehat yang dietnya kaya fenolik terjadi penurunan rasio kolesterol terhadap HDL.

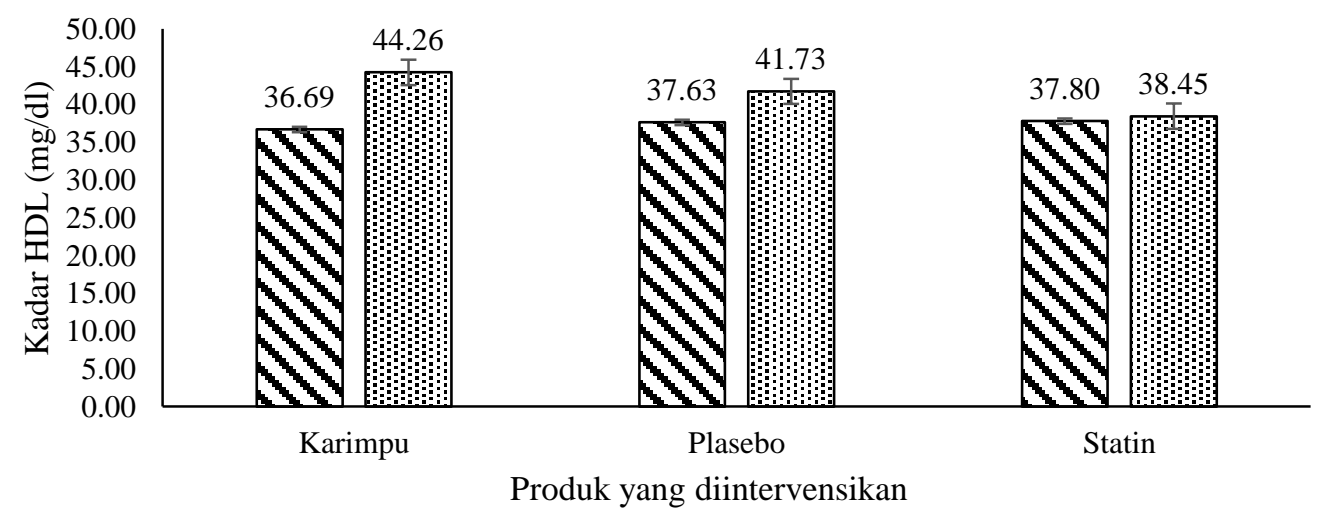

Gambar 2. Efek Karimpu terhadap kadar HDL penderita hiperkolesterolemia.

vHDL

Peningkatan HDL juga dicatat seiring dengan meningkatnya konsentrasi fenolik minyak (Covas et al., 2006). Konsumsi fenolik minyak zaitun menghasilkan peningkatan HDL sirkulasi pada manusia berkisar antara 5,1-6,7\% (Weinbrenner et al., 2004; Marrugat et al., 2004). Peningkatan kadar HDL juga terjadi pada 
tikus aterosklerosis yang diberi rimpang kapulaga (Winarsi et al., 2016), yang diketahui kaya flavonoid. Mekanisme meningkatnya kadar HDL oleh kandungan fenolik Karimpu belum jelas, tetapi Lamon-Fava (2004) menegaskan bahwa flavonoid menaikkan produksi apolipoprotein A1 (Apo-A1) dan regulasi ekspresinya melalui jalur signaling protein kinase yang diaktivasi mitogen. Apolipoprotein-A1 adalah komponen yang berkontribusi pada pembentukan HDL-prebeta, yang kemudian dikonversikan menjadi HDL-alpha, kemudian maturasi melalui proses esterifikasi kolesterol bebas menjadi ester kolesterol oleh enzim lecithin-cholesterol acyl transferase. HDL yang bersifat antiaterogenik, antioksidan, dan anti inflamasi (Younis et al., 2013; Soran et $a l .$, 2015). Karena itu peningkatan kadar HDL memungkinkan dapat menekan progresivitas lesi atherosclerotic.

Kadar LDL saat baseline dalam ketiga kelompok percobaan tidak berbeda $(p=0,23)$. Setelah intervensi kelompok Karimpu, plasebo, maupun statin, kadar LDL ketiganya menurun secara nyata $P=0,0009 ; \quad P=0,029705 ; \quad$ dan $\quad P=$
0,006279 (Gambar 3). Dengan demikian Karimpu, plasebo, dan statin berefek sama dalam menurunkan kadar LDL. Hal yang sama juga terjadi dalam penelitian Gimeno et al. (2002), bahwa kadar LDL menurun secara signifikan setelah satu minggu konsumsi minyak zaitun kaya fenolik. Dalam penelitian ini Karimpu, plasebo, dan statin, ketiganya mampu menurunkan kadar LDL. Penurunannya jelas bukan karena senyawa fenolik, tetapi lebih kepada peran obat statin yang diminum oleh ketiga kelompok tersebut. 


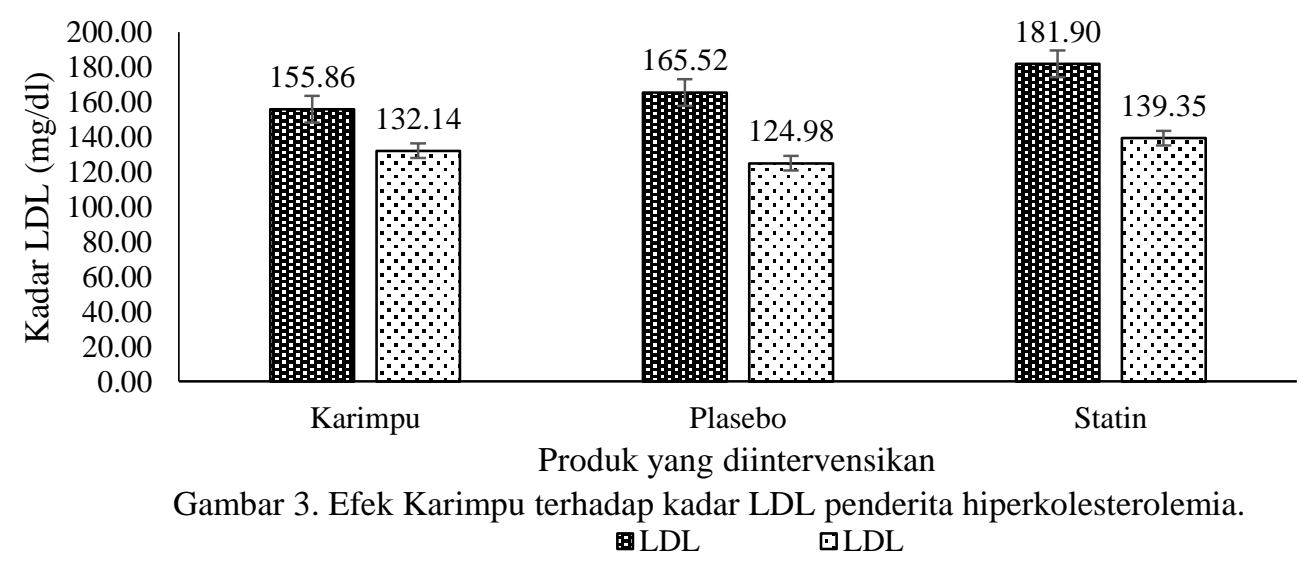

Kadar trigliserida (TG) saat awal homogen, tidak berbeda diantara kelompok $(P=0,29)$. Setelah 2 bulan intervensi ada penurunan kadar trigliserida pada kelompok Karimpu, plasebo, dan statin, tetapi tidak signifikan $(P>0,05)$ (Gambar 4). Dalam penelitian ini tidak terjadi perubahan kadar trigliserida dalam kelompok yang mengonsumsi Karimpu, plasebo, maupun statin, dan kenyataannya terdapat dalam kisaran nilai normal $(167,76 \mathrm{mg} / \mathrm{dl})$ (Siahaan et al., 2015). Menurut Sudhop et al. (2009), kadar trigliserida subjek termasuk kriteria borderline. Dalam mengelola hiperkolesterolemia, perlu dipertimbangkan terapi statin untuk semua pasien, karena agen ini dapat mengurangi mortalitas dan penyakit jantung koroner. Statin dengan potensi tinggi (atorvastatin, rosuvastatin) pada dosis tinggi memiliki khasiat yang lebih besar dalam mengurangi kejadian kardiovaskular daripada statin dengan potensi rendah. Menurut Berglund et al. (2012), pasien yang diobati dengan obat penurun lipid harus dipantau karena dapat berkembang mengarah myositis dan penyakit hati. Selain itu, monoterapi statin tidak dianjurkan untuk hiperkolesterolemia berat. Karena itu back to nature, dengan menggunakan bahan alam seperti minuman berbasis rimpang kapulaga merupakan pilihan bijak, dan banyak digemari masyarakat saat ini. 


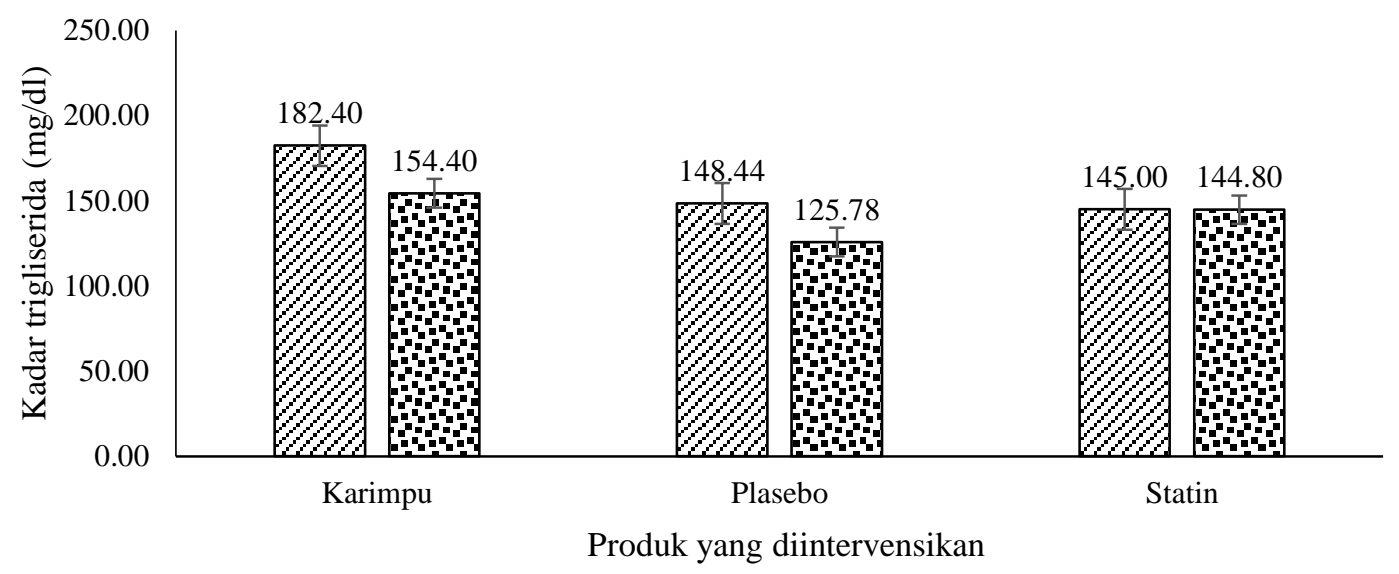

Gambar 4. Efek Karimpu terhadap kadar trigliserida penderita hiperkolesterolemia.

๑Trigliserida $\mathbf{0}$ Trigliserida

\section{Kesimpulan}

Karimpu, minuman berbasis rimpang kapulaga, berbahan alami, mudah dibuat, dan menyehatkan. Karimpu dapat menurunkan kadar kolesterol sebesar $35.98 \%$, dan LDL $15.22 \%$, dan sebaliknya meningkatkan HDL sebanyak 20.63\%, serta mempertahankan kadar trigliserida penderita hiperkolesterolemia.

Kemungkinan, Karimpu dapat menghambat perkembangan hiperkolesterolemia ke arah penyakit kardiovaskular yaitu dengan memperbaiki profil lipidnya.

\section{Ucapan terimakasih}

Dengan penuh syukur penulis
mengucapkan terima kasih kepada
Direktur Jenderal Penelitian dan

Pengabdian kepada Masyarakat, Kementerian Riset, Teknologi dan Pendidikan Tinggi untuk mendanai penelitian Hibah Kompetensi 2017. Terimakasih juga disampaikan kepada Ketua Lembaga Penelitian dan Pengabdian kepada Masyarakat Universitas Jenderal Soedirman atas pendanaan Pengabdian berbasis Riset tahun 2017.

\section{Daftar Pustaka}

Berglund L, Brunzell JD, Goldberg AC, Goldberg IJ, Sacks F, Murad MH, and Stalenhoef AF. 2012. Endocrine society Evaluation and treatment of hypertriglyceridemia: an endocrine society clinical practice guideline. Journal of Clinical Endocrinology and Metabolism 97: 29692989.

Cave M, Deaciuc I, Mendez C, Song Z, JoshiBarve S, and Barve S. 2007. Nonalcoholic fatty liver disease: predisposing factors and the role of nutrition. Journal of Nutritional Biochemistry 18(3): 184-95. 
Chrysohoou Ch, Pitsavos Ch, Skoumas J, Masoura C, Katinioti A, Panagiotakos D, and Stefanadis Ch. 2006. The emerging anti-inflammatory role of HDLcholesterol, illustrated in cardiovascular disease free population. International Journal of Cardiology 122 (1): 29-33.

Cicerale S, Lucas L, and Keast R. 2010. Biological activities of phenolic compounds present in virgin olive oil. International Journal of Molecular Sciences 11(2): 458-479.

Covas MI, Nyyssönen K, Poulsen HE, Kaikkonen J, Zunft HJF, Kiesewetter H, Gaddi A, de la Torre R, Mursu J, Bäumler H, Nascetti S, Salonen JK, Fitó M, Virtanen J, and Marrugat J. 2006. The effect of polyphenols in olive oil on heart disease risk factors: A randomized trial. Annals of Internal Medicine 145 (5): 333341.

Doyle JT, Dawber TR, Kannel WB, Kinch SH, and Kahn HA. 1964. The relationship of cigarette smoking to coronary heart disease; the second report of the combined experience of the Albany and Framingham, mass studies. Journal of the American Medical Association 190: 88690.

Gander J, Sui X, Hazlett LJ, Cai B, Hébert JR, and Blair SN. 2014. Factors related to coronary heart disease risk among men: validation of the Framingham risk score. Preventing Chronic Disease 11: E140. doi: $10.5888 / p c d 11.140045$

Gimeno E, Fitó M, Lamuela-Raventós RM, Castellote AI, Covas M, Farré M, de la Torre-Boronat MC, and López-Sabater MC. 2002. Effect of ingestion of virgin olive oil on human low-density lipoprotein composition. European Journal of Clinical Nutrition 56(2): 114-120.

Ibrahim AM, Yunianta, and Srihertyna FH. 2015. The influence of the temperature and the length of time the extraction of the chemical and physical properties in the manufacture of juice drinks red ginger (Zingiber officinale var. Rubrum) in combination with the addition of honey as a sweetener. Journal of Food and AgroIndustry 2(3): 530-541.

Insull W. 2006. Clinical utility of bile acid sequestrants in the treatment of dyslipidemia: a scientific review. Southern Medical Journal 99(3): 257-73.
Kuamsub S, Singthong P, $\begin{array}{r}\text { Chanthasri } \\ \text { N, Sangkaew }\end{array}$
W, Chobngam
W, Hemdecho Kaewmanee
T, and Chusri S. 2017. Improved lipid
profile associated with daily consumption
of tri-sura-phon in healthy overweight
volunteers: an open-label, randomized
controlled trial. Evidence-Based
Complementary and Alternative
Medicine (2017), Article ID 2687173, 9 p.
https://doi.org/10.1155/2017/2687173.

Lamon-Fava S. 2000. Genistein activates apolipoprotein A-I gene expression in the human hepatoma cell line Hep G2. Journal of Nutrition 130: 2489-92.

Listiyana AD, Mardiana M, dan Prameswari GN. 2013. Obesitas sentral dan kadar kolesterol darah total. Jurnal Kesehatan Masyarakat 9 (1): 37-43.

Marrugat J, Covas MI, Fitó M, Schröder H, MiróCasas E, Gimeno E, López-Sabater MC, de la Torre R, and Farré M. 2000. Effects of differing phenolic content in dietary olive oils on lipids and LDL oxidation a randomized controlled trial. European Journal of Nutrition 43(3): 140-7.

Mitra S, Goyal T, and Mehta JL. 2011. Oxidized LDL, LOX-1 and atherosclerosis. Cardiovascular Drugs and Therapy 25(5): 419-29.

Mulyani S, Harsojuwono BA, dan Puspawati GAKD. 2014. Potensi minuman kunyit asam (Curcuma domestica Val. Tamarindus indica L.) sebagai minuman kaya antioksidan. Agritech 34(1): 65-71.

Ngamukote S, Mäkynen K, Thilawech T, and Adisakwattana S. 2011. Cholesterollowering activity of the major polyphenols in grape seed. Molecules 16: 5054-5061.

Nishida C. 2004. Appropriate body-mass index for Asian populations and its implications for policy and intervention strategies. Lancet 363: 157-63.

Olivera T, Ricardo KFS, Almeida MR, Costa MR, and Nagem TJ. 2007. Hypolipidemic effect of flavonoids and cholestyramine in rats. Latin American Journal of Pharmacy 26: 407-410. 
Prahastuti S, Tjahjani S, and Hartini E. 2011. The effect of bay leaf infusion (Syzygium polyanthun (Wight) Walp) to decrease blood total choleserol level in dyslipidemia model wistar rats. Jurnal Medika Planta 1(4): 29-30.

Siahaan G, Nainggolan E, and Lestrina D. 2015. The correlation between nutritional intake with triglyceride level and blood glucose level in vegetarians. Indonesian Journal of Human Nutrition 2(1) : 48-59.

Soran H, Schofield JD, and Durrington PN. 2015. Antioxidant properties of HDL. Frontiers in Pharmacology 6(222): 1-6.

Squadrito F, Altavilla D, Crisafulli A, Saitta A, Cucinotta D, Morabito N, D'Anna R, Corrado F, Ruggeri P, and Frisina N. 2003. Effect of genistein on endothelial function in postmenopausal women: a randomized, double-blind, controlled study. American Journal of Medicine 114: 470-76.

Sudhop T, Reber M, Tribble D, Sapre A, Taggart W, Gibbons P, Musliner T, von Bergmann K, and Lütjohann D. 2009. Changes in cholesterol absorption and cholesterol synthesis caused by ezetimibe and/or simvastatin in men. Journal of Lipid Research 50: 2117-2123.

Winarsi H. 2015. Ekstrak rimpang kapulaga (Amomum Cardomomum) kaya flavonoid sebagai antioksidan, imunostimulan, dan antiaterosklerosis. Paten P00201508144.

Winarsi $\mathrm{H}$ and Hernayanti. 2016. Functional drinks rich in antioxidant cardamom rhizome. International Food Conference 2016. Surabaya, 20-21 October 2016.

Winarsi H, Sasongko ND, Purwanto A, and Nuraeni I. 2013a. Ekstrak daun kapulaga menurunkan index atherogenik tikus diabetes induksi aloksan. Agritech 33(3): 273-280.

Winarsi H, Sasongko ND, Purwanto A, and Nuraeni I. 2013b. Cardomum leaves extract reduced oxidative stress level in plasma alloxan-induced diabetic rats. Proceeding of $13^{\text {th }}$ Asean Food Conference. Max Atria, Singapore Expo, 9-11 September 2013: p. 250-259.

Winarsi H, Yuniaty A, and Nuraeni I. 2016a. Hypocholesterolemic and attenuated oxidized-LDL of epinephrine-induced atherosclerosis rats using cardamom rhizome ethanolic extract: Study of functional-food components. International Food Research Journal 23(5): 2103-2111.

Winarsi H, Yuniaty A, and Nuraeni I. 2016b. Improvement of antioxidant and immune status of atherosclerotic rats adrenaline and egg-yolks -induced using cardamomrhizome-ethanolic-extract: An initial study of functional food. Agriculture and Agricultural Science Procedia 9: 264-270.

Weinbrenner T, Fitó M, de la Torre R, Saez GT, Rijken P, Tormos C, Coolen S, Albaladejo MF, Abanades S, Schroder H, Marrugat J, and Covas MI. 2004. Olive oils high in phenolic compounds modulate oxidative/antioxidative status in men. Journal of Nutrition 134(9): 2314-21.

Younis NN, Soran H, Charlton-Menys V, Sharma R, Hama S, and Pemberton P. 2013. Highdensity lipoprotein impedes glycation of low-density lipoprotein. Diabetes and Vascular Disease Research 10: 152-160.

Zhu Y, Liao H, Xie X, Yuan Y, Lee TS, and Wang N. 2005. Oxidized LDL downregulates ATP-binding cassette transporter-1 in human vascular endothelial cells via inhibiting liver $\mathrm{X}$ receptor (LXR). Cardiovascular Research 68: 425-432.

Zhang L, Ravipati AS, Koyyalamudi SR, Jeong SC, Reddy N, and Smith PT . 2011. Antioxidant and anti-inflammatory activities of selected medicinal plants containing phenolic and flavonoid compounds. Journal of Agriculture and Food Chemistry 59(23): 12361-67. 